\author{
G. M. Dallinga-Thie $\cdot$ A. van Tol $\cdot$ H. Hattori $\cdot$ \\ L. C. van Vark-van der Zee $\cdot$ H. Jansen • \\ E. J. G. Sijbrands · on behalf of the DALI study group
}

\title{
Plasma apolipoprotein A5 and triglycerides in type 2 diabetes
}

Received: 19 January 2006 / Accepted: 28 February 2006 / Published online: 28 April 2006

C) Springer-Verlag 2006

\begin{abstract}
Aims/hypothesis: Variation in the human apolipoprotein (APO) A5 gene (APOA5) is associated with elevated plasma triglycerides. However, data on the exact role of plasma concentrations of APOA5 in human triglyceride homeostasis are lacking. In the present study, we estimated plasma APOA5 levels in patients with type 2 diabetes at baseline and during atorvastatin treatment, a lipid-lowering treatment that results in a reduction in plasma triglycerides and APOC3. Subjects, materials and methods: Plasma APOA5 concentration was measured by ELISA in 215 subjects with type 2 diabetes, who were taken from the Diabetes Atorvastatin Lipid-lowering Intervention (DALI) study, a 30-week randomised, double-blind, placebo-controlled study, and given atorvastatin $10 \mathrm{mg}$ or $80 \mathrm{mg}$ daily. Results: At baseline, average
\end{abstract}

Members of the DALI study group are listed in the Appendix.

G. M. Dallinga-Thie $(\bowtie) \cdot$ L. C. van Vark-van der Zee •

E. J. G. Sijbrands

Department of Vascular Medicine and Metabolism,

Room Bd 277, Erasmus Medical Center Rotterdam,

P.O. Box 2040, 3000 CA Rotterdam, The Netherlands

e-mail: g.dallinga@erasmusmc.nl

Tel.: +31-10-4632707

Fax: +31-10-4633964

A. van Tol

Department of Cell Biology and Genetics,

Erasmus University Medical Centre,

Rotterdam, The Netherlands

A. van Tol

Department of Endocrinology,

University Medical Centre Groningen,

Groningen, The Netherlands

H. Hattori

Department of Advanced Medical Technology

and Development, BML,

Saitama, Japan

H. Jansen

Department of Clinical Chemistry,

Erasmus University Medical Centre,

Rotterdam, The Netherlands plasma APOA5 concentration was $25.7 \pm 15.6 \mu \mathrm{g} / 100 \mathrm{ml}$. Plasma APOA5 $\left(R_{\mathrm{s}}=0.40\right)$, APOC $3\left(R_{\mathrm{s}}=0.72\right)$ and APOE $\left(R_{\mathrm{S}}=0.45\right)$ were positively correlated with plasma triglyceride levels (all $p<0.001$ ). In multiple linear regression analysis, adjusted for age and sex, the variation in plasma triglycerides was explained mostly by APOC3 (52\%) and only to a small extent by APOA5 (6\%) and APOE (1\%). Atorvastatin treatment decreased plasma triglycerides, APOA5, APOC3 and APOE (all $p<0.0001$ ). After treatment, APOC3 remained the major determinant of plasma triglyceride levels $(59 \%)$, while the contributions of APOA5 and APOE were insignificant (2 and 3\%). Conclusions/interpretation: Our findings reveal a positive association between plasma APOA5 and triglycerides in patients with type 2 diabetes. Treatment with atorvastatin decreased plasma APOA5, APOC3, APOE and triglycerides. In contrast to APOC3, APOA5 is not a major determinant of triglyceride metabolism in these patients.

Keywords Apolipoprotein A5 - Apolipoprotein C3 . Atorvastatin

Abbreviations APO: apolipoprotein - DALI: Diabetes Atorvastatin Lipid-lowering Intervention

\section{Introduction}

Plasma triglyceride levels have been recognised as an independent risk factor for coronary artery disease $[1,2]$. Genetic variations in the apolipoprotein (APO) gene cluster APOA1-C3-A4, located on chromosome 11, are associated with plasma triglyceride concentrations [3]. APOA1, the major structural protein of HDL-cholesterol plays a key role in reverse cholesterol transport [4]. APOC3 is a critical factor in VLDL-triglyceride metabolism [5]. The physiological role of APOA4 is still largely unknown, except for its postulated function as a satiety factor or as a co-factor for intestinal fat absorption [6]. Recently, the $A P O A 5$ gene has been identified, and is located adjacent to the $A P O A 1$ $C 3-A 4$ gene cluster [7]. The $A P O A 5$ gene displays close 
homology with the $A P O A 4$ gene and shows high sequence homology between man, mouse, rat and chicken [8]. Mice that are deficient in APOA5 exhibit markedly elevated plasma triglyceride levels $[7,9]$, but in contrast, mice overexpressing the human $A P O A 5$ gene have decreased plasma triglyceride levels as a function of the level of APOA5 expression $[7,10,11]$. Based on these studies in mice, an opposing role for APOA5 and APOC3 in triglyceride metabolism has been proposed. Human studies have focused upon the association between genetic variation in the APOA5 gene and plasma triglyceride levels. Two common APOA5 polymorphisms, the $-1131 \mathrm{~T} \rightarrow \mathrm{C}$ polymorphism and the $\mathrm{c} 56 \mathrm{C} \rightarrow \mathrm{G}(\mathrm{S} 19 \mathrm{~W})$ polymorphism in the APOA5 signal peptide, are of particular interest [12, 13]. The rare alleles of each polymorphism both show a positive association with elevated plasma triglyceride levels in clinical studies as well as in the general population.

Based on the data from human and animal studies, we hypothesised that the following would apply in patients with type 2 diabetes mellitus: (1) plasma APOA5 concentration will be negatively associated with plasma triglyceride levels; (2) genetic variations in the APOA5 gene determine plasma APOA5 levels; and (3) the major reductions of APOB-containing triglyceride-rich lipoproteins, APOE and APOC 3 that are achieved by atorvastatin treatment may coincide with an increase in plasma APOA5 concentrations.

In the present study, we tested these hypotheses by determining plasma APOA5, APOC3, APOE and triglyceride levels, and assessing genetic variation in the $A P O A 1-C 3-A 4-A 5$ gene cluster in patients with type 2 diabetes in the Diabetes Atorvastatin Lipid-lowering Intervention (DALI) study; this is a double-blind, randomised, placebo-controlled trial comparing the effects of atorvastatin at a dose of $10 \mathrm{mg}$ daily or $80 \mathrm{mg}$ daily on plasma lipids and apolipoproteins in patients with type 2 diabetes, selected for the presence of hypertriglyceridaemia [14]. We have shown that statin treatment leads to a marked decrease in plasma APOC3 levels in patients with type 2 diabetes [15].

\section{Subjects, materials and methods}

\section{Study protocol}

The present study comprised 215 patients enrolled in the DALI study. DALI was a double-blind, randomised, placebo-controlled, multi-centre study, evaluating the effect of atorvastatin 10 vs $80 \mathrm{mg}$ daily on lipid metabolism, endothelial function, coagulation and inflammatory factors in unrelated men and women with type 2 diabetes selected for the presence of mild hypertriglyceridaemia. The protocol and eligibility criteria have been described in detail elsewhere [14]. Briefly, men and women aged 45-75 years, with diabetes of at least 1 year duration and an $\mathrm{HbA}_{1 \mathrm{c}}$ equal to or below $10 \%$ were eligible. The diagnosis of type 2 diabetes was defined according to the American Diabetes Association classification, published in 2000 [16]. Lipid inclusion criteria were: total cholesterol between 4.0 and $8.0 \mathrm{mmol} / \mathrm{l}$ and fasting triglycerides between 1.5 and $6.0 \mathrm{mmol} / \mathrm{l}$. Patients were excluded when they had a history of myocardial infarction, percutaneous transluminal coronary angioplasty, coronary artery bypass graft or clinical symptoms of manifest coronary artery disease. When applicable, lipidlowering drugs were withdrawn at least 8 weeks before the start of the run-in phase. Patients were recruited in Leiden, Rotterdam and Utrecht, the Netherlands. The ethical committees of the participating centres approved the study protocol and written informed consent was obtained from all subjects.

After an overnight fast for a minimum of $12 \mathrm{~h}$, blood was drawn into EDTA-containing tubes for analysis of lipid profiles at baseline and after treatment for 30 weeks. Plasma was prepared by immediate centrifugation $(1,800 \mathrm{~g}$, $15 \mathrm{~min}, 4^{\circ} \mathrm{C}$ ), and samples were stored at $-80^{\circ} \mathrm{C}$ until further analyses. Cholesterol, triglycerides, HDL-cholesterol and LDL-cholesterol, APOA1 and APOB were measured as described previously [14]. Plasma APOE was analysed automatically with a nephelometric assay (Wako, Osaka, Japan). Plasma APOC3 was analysed with a commercially available electroimmunoassay (Hydragel LP CIII, Sebia, Issey-les-Moulineaux, France). Fasting plasma glucose was determined on a Hitachi 917 analyser using an UV-hexokinase method (Cat. No. 18766899, Boehringer Mannheim, Mannheim, Germany). $\mathrm{HbA}_{1 \mathrm{c}}$ was determined by HPLC, using the BIO-RAD Variant TM method (Cat. No. 270-0003, Bio-Rad, Richmond, CA, USA). Plasma APOA5 concentration was measured using a recently developed sandwich ELISA as described [17]. The monoclonal antibody B10E was used for capture and biotinylated monoclonal antibody E8E was used for detection. For calibration of the ELISA, purified bacterial rh-APOA5 was used as primary calibrator. The day-to-day variation and between-plate and within-day variations in the ELISA were 5.5 and $2.2 \%$, respectively.

Polymorphisms in the $A P O C 3$ and $A P O A 1$ genes were assessed as described elsewhere [18]. The APOA5 $\mathrm{c} 56 \mathrm{C} \rightarrow \mathrm{G}(\mathrm{S} 19 \mathrm{~W})$ polymorphism was determined essentially as described, using an identical set of forward and reverse primers [13]. The PCR conditions were: initial denaturing at $95^{\circ} \mathrm{C}$ for $10 \mathrm{~min}$, followed by 35 cycles of $1 \mathrm{~min}$ at $58^{\circ} \mathrm{C} / 30 \mathrm{~s}$ at $72^{\circ} \mathrm{C}$ and a final extension of $7 \mathrm{~min}$ at $72^{\circ} \mathrm{C}$. The restriction enzyme Taq 1 was used to define the alleles. The $-1131 \mathrm{~T} \rightarrow \mathrm{C}$ polymorphism was analysed as described previously [13]. The PCR conditions were: initial denaturing at $95^{\circ} \mathrm{C}$ for $10 \mathrm{~min}$, followed by 35 cycles of $1 \mathrm{~min}$ at $95^{\circ} \mathrm{C} / 1 \mathrm{~min}$ at $58^{\circ} \mathrm{C} / 1 \mathrm{~min}$ at $72^{\circ} \mathrm{C}$ and a final extension of $7 \mathrm{~min}$ at $72^{\circ} \mathrm{C}$. TrulI was used to define the alleles.

\section{Statistical analyses}

The statistical analyses were carried out with SPSS software (version 12). All data are expressed as mean \pm 
Table 1 Baseline characteristics of the study cohort

\begin{tabular}{|c|c|c|c|}
\hline & $\begin{array}{l}\text { Placebo } \\
(n=71)\end{array}$ & $\begin{array}{l}\text { Atorvastatin } 10 \\
\mathrm{mg}(n=72)\end{array}$ & $\begin{array}{l}\text { Atorvastatin } 80 \\
\mathrm{mg}(n=72)\end{array}$ \\
\hline Age (years) & $59 \pm 8$ & $60 \pm 8$ & $60 \pm 8$ \\
\hline BMI $\left(\mathrm{kg} / \mathrm{m}^{2}\right)$ & $32.2 \pm 6.1$ & $30.0 \pm 3.8$ & $30.4 \pm 4.5$ \\
\hline $\mathrm{HbA}_{1 \mathrm{c}}(\%)$ & $8.8 \pm 1.3$ & $8.7 \pm 1.3$ & $8.9 \pm 1.2$ \\
\hline Glucose (mmol/l) & $10.5 \pm 3.6$ & $10.5 \pm 3.0$ & $10.6 \pm 2.9$ \\
\hline $\begin{array}{l}\text { Cholesterol } \\
(\mathrm{mmol} / \mathrm{l})\end{array}$ & $6.0 \pm 0.9$ & $5.9 \pm 0.9$ & $6.0 \pm 0.9$ \\
\hline $\begin{array}{l}\text { HDL-cholesterol } \\
(\mathrm{mmol} / \mathrm{l})\end{array}$ & $1.05 \pm 0.21$ & $1.05 \pm 0.26$ & $1.03 \pm 0.24$ \\
\hline $\begin{array}{l}\text { APOA1 (mg/100 } \\
\mathrm{ml})\end{array}$ & $141 \pm 19$ & $139 \pm 20$ & $139 \pm 21$ \\
\hline $\begin{array}{l}\text { APOB (mg/100 } \\
\mathrm{ml})\end{array}$ & $128 \pm 19$ & $122 \pm 21$ & $124 \pm 23$ \\
\hline
\end{tabular}

All data are expressed as mean $\pm \mathrm{SD}$

APO Apolipoprotein

standard deviation (SD). Mean differences between the groups were analysed using analysis of variance. Deviations from Hardy-Weinberg equilibrium were assessed using a $\chi^{2}$ test. To analyse the determinants of plasma triglycerides we used the following strategy. The raw data were presented as plotted correlations between apolipoproteins and triglycerides with Spearman correlation coefficients. Multiple linear regression analysis was performed with triglyceride as the dependent outcome variable; adjustment was made for sex and age, HDLcholesterol and APOE levels. The contribution of plasma APOA5 and APOC3 to triglyceride levels was estimated simultaneously by entering them together with all covariables concomitantly into the analysis. In addition, we calculated the partial explained variance (partial $r^{2}$ ) as the difference between the $r^{2}$ of the model with all the covariables and the $r^{2}$ of repeated analyses after removing a specific variable from the model. We also used a stepwise linear regression model to test for the presence of significant determinants in our database, but this did not yield additional contributors. The placebo-controlled effect of treatment on lipid and apolipoprotein variables was analysed with two-way analysis of covariance, using a placebo-controlled setting. In addition, we used a matched multiple linear regression model to estimate the effects of treatment. Throughout, a two-tailed $p$ value $<0.05$ was interpreted as indicating a statistically significant difference.

\section{Results}

Selected baseline characteristics are shown in Table 1, but have also been published in more detail elsewhere [14]. The patients had elevated plasma triglycerides $(2.8 \pm 1.0$ $\mathrm{mmol} / \mathrm{l})$ and decreased plasma HDL-cholesterol (1.04 \pm $0.24 \mathrm{mmol} / \mathrm{l}$ ). Mean plasma LDL-cholesterol was $3.7 \pm 0.9$ $\mathrm{mmol} / \mathrm{l}$. Mean fasting plasma glucose level was 10.6 $\mathrm{mmol} / \mathrm{l}$ and $\mathrm{HbA}_{1 \mathrm{c}}$ was $8.7 \%$. Baseline plasma APOA5 level varied from 7.0 to $139.8 \mu \mathrm{g} / 100 \mathrm{ml}$, with a mean of $25.7 \pm 15.6 \mu \mathrm{g} / 100 \mathrm{ml}$. APOC3 levels ranged from 22 to $68 \mathrm{mg} / 100 \mathrm{ml}$ (mean: $41.4 \pm 9.9 \mathrm{mg} / 100 \mathrm{ml}$ ), and APOE ranged from 2.5 to $8.7 \mathrm{mg} / 100 \mathrm{ml}$ (mean $4.5 \pm 1.0 \mathrm{mg} / 100$ $\mathrm{ml}$ ) (Table 2). There were no differences between the three treatment groups. The unadjusted correlation between plasma triglycerides and APOA5 $\left(R_{\mathrm{s}}=0.399, p<0.001\right)$ is shown in Fig. 1. The correlation between plasma triglycerides and plasma APOC3 was $0.721 \quad(p<0.001)$, and that between plasma triglycerides and plasma APOE was $0.449(p<0.001)$. At baseline, the co-variables (Table 3) explained $76 \%$ of the variance in plasma triglycerides $\left(r^{2}=0.756, p<0.001\right)$. Plasma APOC3 was the strongest contributor to the variation in plasma triglyceride levels $\left(r^{2}=0.520, p<0.001\right)$, whereas HDL-cholesterol was the only lipid parameter showing a significant contribution $\left(r^{2}=0.155, p<0.001\right)$. In contrast, APOA5 and APOE only contributed to a small extent. The relative importance of each parameter in the variation in plasma triglycerides was illustrated by calculating the change in plasma triglyceride
Table 2 Effect of 30 weeks atorvastatin treatment on plasma apolipoproteins and plasma triglyceride levels

Data are represented as mean $\pm \mathrm{SD}$ and statistically analysed with ANOVA $T G$ Triglycerides, $A P O$ apolipoprotein

\begin{tabular}{|c|c|c|c|c|}
\hline & Placebo & Atorvastatin $10 \mathrm{mg}$ & Atorvastatin $80 \mathrm{mg}$ & $p$ value \\
\hline \multicolumn{5}{|c|}{ APOA5 $(\mu \mathrm{g} / 100 \mathrm{ml})$} \\
\hline Baseline & $26.4 \pm 19.8$ & $24.3 \pm 11.6$ & $26.6 \pm 14.9$ & NS \\
\hline 30 weeks & $27.5 \pm 21.3$ & $20.7 \pm 12.7$ & $17.3 \pm 7.5$ & $<0.001$ \\
\hline Change & & $-15.1 \%$ & $-35.1 \%$ & \\
\hline \multicolumn{5}{|c|}{ APOC3 $(\mathrm{mg} / 100 \mathrm{ml})$} \\
\hline Baseline & $41.2 \pm 9.0$ & $39.8 \pm 9.4$ & $43.2 \pm 11.2$ & NS \\
\hline 30 weeks & $41.0 \pm 12.0$ & $31.8 \pm 10.6$ & $31.1 \pm 11.3$ & $<0.001$ \\
\hline Change & & $-21.1 \%$ & $-27.2 \%$ & \\
\hline \multicolumn{5}{|c|}{$\operatorname{APOE}(\mathrm{mg} / 100 \mathrm{ml})$} \\
\hline Baseline & $4.5 \pm 0.8$ & $4.3 \pm 1.0$ & $4.7 \pm 1.2$ & NS \\
\hline 30 weeks & $4.5 \pm 1.1$ & $3.2 \pm 0.8$ & $3.0 \pm 1.0$ & $<0.001$ \\
\hline Change & & $-28.0 \%$ & $-36.0 \%$ & \\
\hline \multicolumn{5}{|c|}{ TG $(\mathrm{mmol} / \mathrm{l})$} \\
\hline Baseline & $2.8 \pm 1.0$ & $2.7 \pm 0.9$ & $3.0 \pm 1.1$ & NS \\
\hline 30 weeks & $2.9 \pm 1.7$ & $1.8 \pm 0.8$ & $1.8 \pm 0.6$ & $<0.001$ \\
\hline Change & & $-25.4 \%$ & $-34.6 \%$ & \\
\hline
\end{tabular}




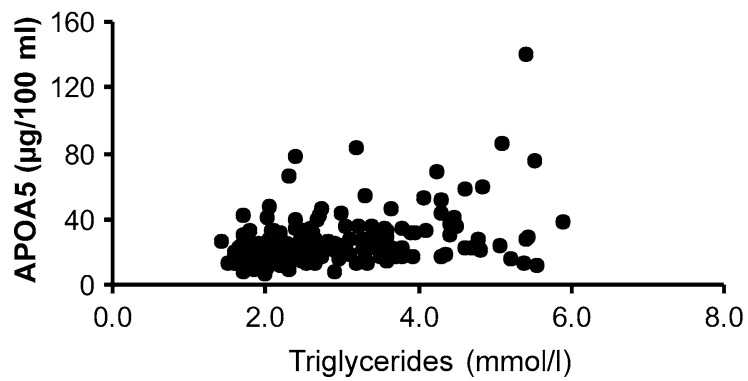

Fig. 1 Unadjusted correlation between APOA5 and plasma triglycerides. The Spearman correlation coefficient was $R_{\mathrm{s}}=0.399$, $p<0.001$

upon a $10 \%$ change in the individual determinant (Table 4). A $10 \%$ change in plasma APOC3 levels $(4.2 \mathrm{mg} / 100 \mathrm{ml})$ was associated with a change in plasma triglycerides of $0.26 \mathrm{mmol} / \mathrm{l}$. In contrast, a change of $10 \%$ in plasma APOA5 levels was associated with a change in plasma triglycerides of only $0.025 \mathrm{mmol} / \mathrm{l}$.

In the present study, the $\mathrm{c} 56 \mathrm{C} \rightarrow \mathrm{G}$ and $-1131 \mathrm{~T} \rightarrow \mathrm{C}$ variants in the $A P O A 5$ gene, the $3238 \mathrm{C} \rightarrow \mathrm{G}$ polymorphism in the $A P O C 3$ gene and the $-78 \mathrm{G} \rightarrow \mathrm{A}$ polymorphism in the $A P O A 1$ gene promoter were analysed. Effects of these genotypes on plasma APOA5 levels are presented in Fig. 2. The effects of the APOA5 gene variants on plasma triglyceride concentrations at baseline are presented in Table 5. All polymorphisms were in Hardy-Weinberg equilibrium $\left(\chi^{2}<0.178, \mathrm{df}=1, p>0.6\right)$. The heterozygous carriers of the $A P O A 5: \mathrm{c} 56 \mathrm{G}$ variant and the heterozygous carriers of the APOA1:-78G variant had increased levels of plasma APOA5 $(p<0.01)$. In contrast, the heterozygous carriers of the $A P O C 3$ gene variant and the $-1131 \mathrm{~T} \rightarrow \mathrm{C}$ polymorphism in the APOA5 gene were associated with lower plasma APOA5 levels $(p<0.05)$. No significant associations with plasma triglycerides were observed.

We have previously reported that atorvastatin significantly decreased plasma total cholesterol and LDL-cholesterol, as well as triglycerides, in type 2 diabetic subjects in the DALI study [14]. In addition, atorvastatin treatment, 10 or $80 \mathrm{mg}$ daily, resulted in a dose-dependent decrease of plasma APOC3 (21 and 27\%, respectively, $p<0.001$ ) [15] and APOE (28 and 36\%, respectively; $p<0.001$, Table 2 ). Atorvastatin $10 \mathrm{mg}$ and atorvastatin $80 \mathrm{mg}$ reduced plasma

Table 3 Effect of baseline determinants on plasma triglyceride variation determined by multivariate linear regression analyses

\begin{tabular}{lcll}
\hline Determinants & Triglyceride $(\mathrm{mmol} / \mathrm{l})(\beta)$ & $p$ value & $r^{2}$ \\
\hline Constant & 1.458 & & \\
Age (year) & -0.11 & 0.04 & 0.006 \\
Sex & 0.176 & 0.02 & 0.008 \\
APOC3 $(\mathrm{mg} / 100 \mathrm{ml})$ & 0.062 & 0.001 & 0.520 \\
HDLc $(\mathrm{mmol} / \mathrm{l})$ & -1.502 & 0.001 & 0.155 \\
APOA5 $(\mu \mathrm{g} / 100 \mathrm{ml})$ & 0.015 & 0.001 & 0.060 \\
APOE $(\mathrm{mg} / 100 \mathrm{ml})$ & 0.121 & 0.001 & 0.011 \\
Total & & & 0.76 \\
\hline
\end{tabular}

$A P O$ Apolipoprotein, $H D L c$ HDL-cholesterol
Table 4 Change of plasma triglyceride levels induced by a $10 \%$ increase of APOC3, APOA5, APOE and HDL-cholesterol at baseline

\begin{tabular}{lll}
\hline Determinant & $\begin{array}{l}\text { Mean plasma } \\
\text { concentration }\end{array}$ & $\begin{array}{l}\text { Change in plasma } \\
\text { triglyceride }(\mathrm{mmol} / \mathrm{l})\end{array}$ \\
\hline $\begin{array}{l}\text { APOC3 }(\mathrm{mg} / 100 \\
\mathrm{ml})\end{array}$ & 41.4 & 0.26 \\
$\begin{array}{l}\text { APOA5 }(\mu \mathrm{g} / 100 \\
\mathrm{ml})\end{array}$ & 25.7 & 0.025 \\
$\begin{array}{l}\text { APOE }(\mathrm{mg} / 100 \\
\mathrm{ml})\end{array}$ & 4.5 & 0.054 \\
$\begin{array}{l}\mathrm{HDL}-\mathrm{cholesterol} \\
(\mathrm{mmol} / \mathrm{l})\end{array}$ & 1.0 & -0.16
\end{tabular}

The $\beta$ values of Table 3 and the $10 \%$ of the mean value of the determinants were used to calculate effects on plasma triglycerides APO Apolipoprotein

APOA 5 by 15 and $35 \%$, respectively $(p<0.001 ; 10$ vs 80 mg $p<0.001)$. In a matched multiple linear regression model, we estimated the placebo-controlled contributions of APOA5, APOC3, APOE, APOB and HDL-cholesterol to variations in the decrease in triglyceride level during atorvastatin treatment. The decrease in APOC3 explained $59 \%$ of the variance of triglyceride reduction $\left(r^{2}=0.588\right.$, $p<0.001)$. The contributions of the decreases in APOA5 $\left(r^{2}=0.015\right)$ and APOB $\left(r^{2}=0.005\right)$ were negligible, whereas the contributions of the decrease in APOE $\left(r^{2}=0.098\right)$ and the increase in HDL-cholesterol $\left(r^{2}=0.045\right)$ were minor. Therefore, despite the relatively large decrease in APOC3 concentrations, it remained the most powerful determinant of plasma triglyceride levels, whereas again the contribution of APOA5 levels was negligible. No effect of genetic variation in the $A P O A 5$ gene on the response to atorvastatin treatment of plasma triglycerides could be demonstrated (Table 5).

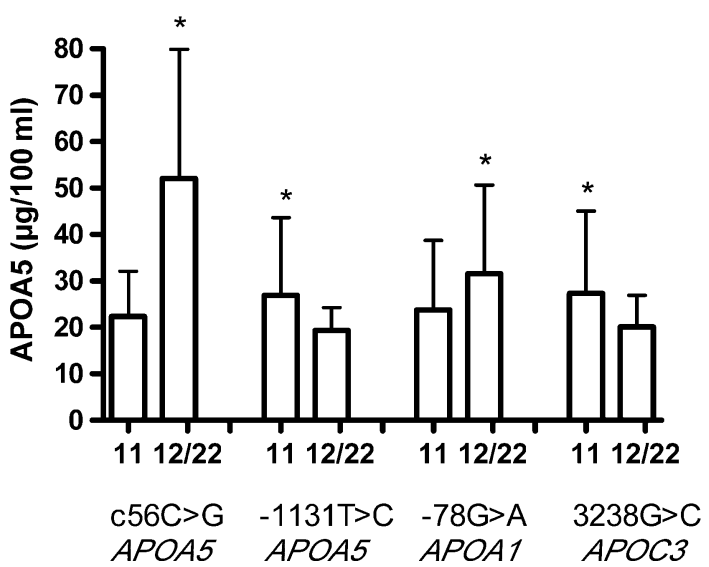

Fig. 2 Effect of genetic variations in the $A P O A 5$ gene $(\mathrm{c} 56 \mathrm{C} \rightarrow \mathrm{G}$, $-1131 \mathrm{~T} \rightarrow \mathrm{C})$, the $A P O A 1$ gene $(-78 \mathrm{G} \rightarrow \mathrm{A})$, and the $A P O C 3$ gene $(3238 \mathrm{G} \rightarrow \mathrm{C})$ on plasma APOA5 concentration. ${ }^{*} p<0.00112 / 22$ vs 11 genotype as measured with unpaired $t$ test statistics 
Table 5 Effect of genetic variation in the $A P O A 5$ gene on plasma triglycerides before and during atorvastatin treatment

\begin{tabular}{|c|c|c|c|c|}
\hline & \multicolumn{2}{|l|}{$-1131 \mathrm{~T} \rightarrow \mathrm{C}$} & \multicolumn{2}{|l|}{ S19W } \\
\hline & $11(n=175)$ & $12 / 22(n=37)$ & $11(n=191)$ & $12 / 22(23)$ \\
\hline Triglycerides & $2.8 \pm 1.0$ & $2.7 \pm 1.0$ & $2.6 \pm 0.9$ & $3.1 \pm 1.3$ \\
\hline \multicolumn{5}{|c|}{$\Delta$ Triglycerides } \\
\hline Placebo & $-0.2 \pm 1.4$ & $0.2 \pm 0.7$ & $-0.1 \pm 1.4$ & $-0.3 \pm 1.0$ \\
\hline $10 \mathrm{mg} \mathrm{A}$ & $0.9 \pm 0.8$ & $0.6 \pm 1.2$ & $0.9 \pm 0.9$ & $0.7 \pm 0.7$ \\
\hline $80 \mathrm{mg} \mathrm{A}$ & $1.1 \pm 1.3$ & $1.5 \pm 1.0$ & $1.2 \pm 1.3$ & $1.8 \pm 0.7$ \\
\hline
\end{tabular}

Data are presented as mean \pm SD. Triglycerides are presented as millimole per liter. No statistically significant differences are present between the 11 and $12 / 22$ genotypes as tested with unpaired $t$ test analyses

$A$ Atorvastatin

\section{Discussion}

The main results obtained in the present study in patients with type 2 diabetes are: (1) plasma APOA5 concentrations are positively associated with plasma triglyceride levels; (2) atorvastatin treatment resulted not only in a decrease in plasma triglycerides, but also in a decrease in plasma APOA5 levels; and (3) APOC3 is a much stronger determinant of plasma triglyceride levels than is APOA5, thereby supporting the notion that plasma APOA5 only plays a minor role in the triglyceride metabolism of patients with type 2 diabetes. Accordingly, several of our original hypotheses, which had been derived from earlier human and animal studies, were disproved, suggesting that the role of APOA5 in triglyceride metabolism may be different in mice and men.

The recent development of specific immunoassays for human APOA5 enables in-depth investigation of the role of APOA5 in human lipoprotein metabolism. APOA5 in human plasma is present on VLDL and HDL particles [19]. However, its total plasma concentration is very low and only about $4 \%$ of VLDL particles carry an APOA5 molecule $[20,21]$. In contrast, all VLDL particles are carrying one or more APOC3 molecules. Average plasma APOA5 levels have been reported in healthy normolipidaemic volunteers of Caucasian origin as $16 \mu \mathrm{g} / 100 \mathrm{ml}$ [19] and $1 \mu \mathrm{g} / 100 \mathrm{ml}$ [22], and in healthy Japanese subjects as $18 \mu \mathrm{g} / 100 \mathrm{ml}$ [17]. In our patients with type 2 diabetes, who were of Caucasian origin and had moderately elevated plasma triglyceride levels, plasma APOA5 levels were 7 to $139 \mu \mathrm{g} / 100 \mathrm{ml}$.

APOA5 has been extensively studied in models of genetically engineered mice. However, the exact molecular mechanism underlying the role of APOA5 in triglyceride metabolism remains unclear. The fractional catabolic rate of VLDL and chylomicron triglycerides was markedly accelerated in both human APOA5 transgenic mice and adenovirus-mediated APOA5-overexpressing mice, and was sharply decreased in APOA5-deficient mice, clearly suggesting a role for APOA5 in the hydrolysis of triglycerides [9, 10, 21, 23]. All these studies, however, were complicated by the fact that APOC3, a well-known inhibitor of lipoprotein lipase activity, is decreased in
APOA5 transgenic mouse models and increased in APOA5-deficient mice [7]. Using a different strategy it was suggested that APOA5 may accelerate the hydrolysis of triglyceride-rich lipoproteins by facilitating their interaction with proteoglycan-bound lipoprotein lipase [21]. However, recently human APOA5 concentration was shown not to be related to VLDL kinetic parameters in 15 healthy control subjects [24]. Moreover, in a postprandial study in patients with type 2 diabetes a lack of correlation between plasma APOA5 levels and an index for lipoprotein lipase activity was found [22]. This was confirmed in the present study where no relationship between plasma APOA5 levels and plasma post-heparin lipoprotein lipase activity could be found (data not shown). These results do not favour a role of human APOA5 in lipoprotein lipase-mediated lipolysis. In conclusion, APOA5 appears to be implicated in triglyceride metabolism in mice by showing a negative association with plasma triglycerides. However, its role in human triglyceride metabolism is largely unknown and may be different, as illustrated by the positive correlation between plasma APOA5 concentration and plasma triglycerides observed in the present study. We compared the relationship between APOA5 and triglycerides with that of two well-known modifiers of triglycerides, namely APOC3 and APOE. In multivariate analyses, APOC 3 was found to be the major independent determinant of plasma triglyceride levels. APOA5, as well as APOE, exerts only minor influence on plasma triglyceride variation.

A number of association studies have been performed. Two common haplotypes were defined: $A P O A 5^{*} 2$ based on $-1131 \mathrm{C} \rightarrow \mathrm{T}$ and $A P O A 5^{*} 3$ based on the $\mathrm{c} 56 \mathrm{C} \rightarrow \mathrm{G}$ polymorphism [8]. Association studies have shown a positive correlation between plasma triglycerides and the rare variant of the $\mathrm{c} 56 \mathrm{C} \rightarrow \mathrm{G}$, as well as the rare variant of the $-1131 \mathrm{~T} \rightarrow \mathrm{C}$ in a number of different populations, patient cohorts, and ethnic groups [7, 12, 13, 25-32]. In the present study, the associations between these genetic variations and plasma triglycerides did not reach statistical significance. In addition, the genetic variations in the APOA5 gene did not affect the triglyceride response during statin treatment. However, genetic variations in the $A P O A 1-C 3-A 4-A 5$ gene cluster were clearly associated with differences in plasma APOA5 levels (Fig. 2). Variations in the $A P O C 3$ gene $(3238 \mathrm{G} \rightarrow \mathrm{C})$ and the $A P O A 5-1131 \mathrm{C}>\mathrm{T}$ polymorphism are associated with decreased plasma APOA5 levels whereas other variations in the APOA1 $(-78 \mathrm{G} \rightarrow \mathrm{A})$ and $A P O A 5(\mathrm{c} 56 \mathrm{C} \rightarrow \mathrm{G})$ genes are associated with elevated plasma APOA5 concentrations. The present study was too small to perform meaningful haplotype analyses, but it has been suggested that the minor allele of the $A P O A 1$ promoter polymorphism is on the same haplotype as the minor allele of c $56 \mathrm{C} \rightarrow \mathrm{G}$, which could provide an explanation for the observed relationship [30]. The S19W $(\mathrm{c} 56 \mathrm{C} \rightarrow \mathrm{G})$ polymorphism located in the signal peptide is predicted to have an effect on APOA5 gene transcription [33], whereas results from in vitro expression studies suggested that the $-1131 \mathrm{~T} \rightarrow \mathrm{C}$ may not be a functional polymorphism [33]. However, we 
do find a significant association with plasma APOA5 levels, although in the opposite direction to the $\mathrm{c} 56 \mathrm{C} \rightarrow \mathrm{G}$ polymorphism. It is evident that larger association studies are required to fully understand the effect of genetic variation in the APOA1-C3-A4-A5 gene cluster on plasma APOA5 levels. We cannot rule out the possibility that the frequently observed associations between APOA5 gene polymorphisms and plasma triglycerides may not involve the APOA5 protein. The APOA5 gene may be in strong linkage disequilibrium with an as yet unknown gene which is strongly related to plasma triglycerides. This will not be $A P O C 3$, because genetic variation in the $A P O C 3$ gene does not explain the observed relationship between APOC3 and triglycerides.

A weakness of our study is that we restricted our analyses to patients with type 2 diabetes and therefore we cannot test the general validity of our findings. The strength of our study is that we were able to analyse the placebo-controlled effect of two dosages of atorvastatin. This experiment facilitated analyses in the same individual with a difference in lipid and apolipoprotein levels. Atorvastatin treatment resulted in a decrease of plasma triglycerides, APOA5, APOC3, APOE and APOB, as well as of VLDL- and LDL-cholesterol. In multivariate analyses, the decrease in APOC 3 correlated strongly with the decrease in triglycerides whereas the contributions of APOA5 and APOE were almost negligible. Hence, in patients with type 2 diabetes, APOA5 had made a substantial contribution to neither the baseline triglyceride levels, nor the effect of atorvastatin treatment on triglyceride levels when APOC3 levels were decreased. Whether atorvastatin can directly affect $A P O A 5$ gene expression remains to be established. It has been shown that fibrates inhibit APOA5 mRNA, indicating the presence of a peroxisome proliferator-activated receptor- $\alpha$ (PPAR- $\alpha$ ) response element in the gene promoter [34], and it has been shown that atorvastatin has PPAR- $\alpha$-inhibiting potential [35].

In conclusion, our study shows that APOA5, present in human plasma in a low concentration compared with APOC3, plays a relatively modest role as a regulator of triglyceride homeostasis in patients with type 2 diabetes. However, it cannot be ruled out that APOA5 acts locally in the liver, its tissue site of origin, via as yet unknown mechanisms.

Acknowledgements The authors wish to thank all the persons who have contributed to the DALI study as patient, technician or data manager. The original DALI study was an investigator-driven study partly supported by an unrestricted grant from Parke-Davis, the Netherlands.

Duality of interest The authors declare that they have no duality of interest.

\section{Appendix}

DALI-study group (in alphabetical order): Erasmus Medical Centre Rotterdam, Department of Internal Medicine
(I. Berk-Planken, N. Hoogerbrugge, H. Jansen); Erasmus University Rotterdam, Departments of Biochemistry and Clinical Chemistry (H. Jansen); Gaubius Laboratory TNO-KvL, Leiden (H. M. G. Princen); Leiden University Medical Centre (M. V. Huisman, M. A. van de Ree); University Medical Centre Utrecht, Julius Centre for General Practice and Patient Oriented Research (R. P. Stolk, F. V. van Venrooij); University Medical Centre Utrecht, Division of Internal Medicine (J. D. Banga, G. M. Dallinga-Thie, F. V. van Venrooij).

\section{Reference}

1. Austin MA, McKnight B, Edwards KL et al (2000) Cardiovascular disease mortality in familial forms of hypertriglyceridemia: a 20-year prospective study. Circulation 101:2777-2782

2. Hokanson JE, Austin MA (1996) Plasma triglyceride is a risk factor for cardiovascular disease independent of high density lipoprotein cholesterol: a meta analysis of population based prospective studies. J Cardiovasc Res 3:213-219

3. Groenendijk M, Cantor RM, De Bruin TWA, Dallinga-Thie GM (2001) The apoAI-CIII-AIV gene cluster. Atherosclerosis $157: 1-11$

4. Brewer HB Jr, Rader DJ (1991) HDL: structure, function and metabolism. Prog Lipid Res 30:139-144

5. Jong MC, Hofker MH, Havekes LM (1999) Role of ApoCs in lipoprotein metabolism-functional differences between ApoC1, ApoC2, and ApoC3. Arterioscler Thromb Vasc Biol 19:472-484

6. Fujimoto K, Cardelli JA, Tso P (1992) Increased apolipoprotein AIV in rat mesenteric lymph after lipid meal acts as a physiological signal for satiation. Am J Physiol 262:G1002-G1006

7. Pennacchio LA, Olivier M, Hubacek JA et al (2001) An apolipoprotein influencing triglycerides in humans and mice revealed by comparative sequencing. Science 294:169-173

8. Pennacchio LA, Rubin EM (2003) Apolipoprotein A5, a newly identified gene that affects plasma triglyceride levels in humans and mice. Arterioscler Thromb Vasc Biol 23:529-534

9. Grosskopf I, Baroukh N, Lee SJ et al (2005) Apolipoprotein A-V deficiency results in marked hypertriglyceridemia attributable to decreased lipolysis of triglyceride-rich lipoproteins and removal of their remnants. Arterioscler Thromb Vasc Biol 25:2573-2579

10. Fruchart-Najib J, Bauge E, Niculescu LS et al (2004) Mechanism of triglyceride lowering in mice expressing human apolipoprotein A5. Biochem Biophys Res Commun 319:397-404

11. Vliet HNvd, Schaap FG, Levels JH et al (2002) Adenoviral overexpression of apolipoprotein A-V reduces serum levels of triglycerides and cholesterol in mice. Biochem Biophys Res Commun 295:1156-1159

12. Pennacchio LA, Olivier M, Hubacek JA, Krauss RM, Rubin EM, Cohen JC (2002) Two independent apolipoprotein A5 haplotypes influence human plasma triglyceride levels. Hum Mol Genet 11:3031-3038

13. Talmud PJ, Hawe E, Martin S et al (2002) Relative contribution of variation within the ApoC3/A4/A5 gene cluster in determining plasma triglycerides. Hum Mol Genet 11:3039-3046

14. Berk-Planken II, Hoogerbrugge N, Jansen H et al (2001) The effect of aggressive versus standard lipid lowering by atorvastatin on diabetic dyslipidemia-The DALI Study: a double-blind, randomized, placebo-controlled trial in patients with type 2 diabetes and diabetic dyslipidemia. Diabetes Care 24:1335-1341

15. Dallinga-Thie GM, Berk-Planken II, Bootsma AH, Jansen H (2004) Atorvastatin decreases apolipoprotein C-III in apolipoprotein B-containing lipoprotein and HDL in type 2 diabetes: a potential mechanism to lower plasma triglycerides. Diabetes Care 27:1358-1364 
16. No authors listed (2000) Report of the expert committee on the diagnosis and classification of diabetes mellitus. Diabetes Care 23:S4-S19

17. Ishihara M, Kujiraoka T, Iwasaki T et al (2005) A sandwich enzyme-linked immunosorbent assay for human plasma apolipoprotein A-V concentration. J Lipid Res 46:2015-2022

18. Dallinga-Thie GM, Bu XD, Trip MV, Rotter JI, Lusis AJ, De Bruin TWA (1996) Apolipoprotein A-I/C-III/A-IV gene cluster in familial combined hyperlipidemia: effects on LDL-cholesterol and apolipoproteins B and C-III. J Lipid Res 37:136-147

19. O'Brien PJ, Alborn WE, Sloan JH et al (2005) The novel apolipoprotein A5 is present in human serum, is associated with VLDL, HDL, and chylomicrons, and circulates at very low concentrations compared with other apolipoproteins. Clin Chem 51:351-359

20. Olofsson SO (2005) ApoA-V: the regulation of a regulator of plasma triglycerides. Arterioscler Thromb Vasc Biol 25:1097-1099

21. Merkel M, Loeffler B, Kluger M et al (2005) Apolipoprotein $\mathrm{AV}$ accelerates plasma hydrolysis of triglyceride-rich lipoproteins by interaction with proteoglycan-bound lipoprotein lipase. J Biol Chem 280:21553-21560

22. Pruneta-Deloche V, Ponsin G, Groisne L, Fruchart-Najib J, Lagarde M, Moulin P (2005) Postprandial increase of plasma apoAV concentrations in type 2 diabetic patients. Atherosclerosis 181:403-405

23. Baroukh N, Bauge E, Akiyama J et al (2004) Analysis of apolipoprotein $\mathrm{A} 5, \mathrm{c} 3$, and plasma triglyceride concentrations in genetically engineered mice. Arterioscler Thromb Vasc Biol 24:1297-1302

24. Chan DC, Watts GF, Nguyen MN, Barrett H (2006) Apolipoproteins $\mathrm{C}$-III and $\mathrm{A}-\mathrm{V}$ as predictors of very-lowdensity lipoprotein triglyceride and apolipoprotein B-100 kinetics. Arterioscler Thromb Vasc Biol 26:590-596

25. Endo K, Yanagi H, Araki J, Hirano C, Yamakawa-Kobayashi K, Tomura S (2002) Association found between the promoter region polymorphism in the apolipoprotein $\mathrm{A}-\mathrm{V}$ gene and the serum triglyceride level in Japanese schoolchildren. Hum Genet 111:570-572
26. Aouizerat BE, Kulkarni M, Heilbron D et al (2003) Genetic analysis of a polymorphism in the human apoA-V gene: effect on plasma lipids. J Lipid Res 44:1167-1173

27. Evans D, Buchwald A, Beil FU (2003) The single nucleotide polymorphism $-1131 \mathrm{~T}>\mathrm{C}$ in the apolipoprotein A5 (ApoA5) gene is associated with elevated triglycerides in patients with hyperlipidemia. J Mol Med 81:645-654

28. Wright WT, Young IS, Nicholls DP, Patterson C, Lyttle K, Graham CA (2005) SNPs at the ApoA5 gene account for the strong association with hypertriglyceridaemia at the ApoA5/ A4/C3/A1 locus on chromosome 11q23 in the Northern Irish population. Atherosclerosis 185:353-360

29. Eichenbaum-Voline S, Olivier M, Jones EL et al (2004) Linkage and association between distinct variants of the ApoA1/C3/A4/A5 gene cluster and familial combined hyperlipidemia. Arterioscler Thromb Vasc Biol 24:167-174

30. Mar R, Pajukanta P, Allayee H et al (2004) Association of the Apolipoprotein A1/C3/A4/A5 gene cluster with triglyceride levels and LDL particle size in familial combined hyperlipidemia. Circ Res 94:993-999

31. Austin MA, Talmud PJ, Farin FM et al (2004) Association of apolipoprotein A5 variants with LDL particle size and triglyceride in Japanese Americans. Biochim Biophys Acta 1688:1-9

32. Martin S, Nicaud V, Humphries SE, Talmud PJ (2003) Contribution of ApoA5 gene variants to plasma triglyceride determination and to the response to both fat and glucose tolerance challenges. Biochim Biophys Acta 1637:217-225

33. Talmud PJ, Palmen J, Putt W, Lins L, Humphries SE (2005) Determination of the functionality of common ApoA5 polymorphisms. J Biol Chem 280:28215-28220

34. Vu-Dac N, Gervois P, Jakel H et al (2003) Apolipoprotein A5, a crucial determinant of plasma triglyceride levels, is highly responsive to peroxisome proliferator-activated receptor alpha activators. J Biol Chem 278:17982-17985

35. Schoonjans K, Peinado-Onsurbe J, Fruchart JC, Tailleux A, Fiévet C, Auwerx J (1999) 3-Hydroxy-3-methylglutaryl CoA reductase inhibitors reduce serum triglyceride levels through modulation of apolipoprotein C-III and lipoprotein lipase. FEBS Lett 452:160-164 